\title{
NON-DESTRUCTIVE ANALYSIS OF THE ROOT SYSTEM AND TREE GROWTH PARAMETERS ${ }^{1}$
}

\author{
Ricardo Anselmo Malinovski², Leif Nutto ${ }^{3}$, Willian Schwegler Wiese ${ }^{4 *}$ and Martin Brunsmeier ${ }^{5}$
}

\footnotetext{
${ }^{1}$ Received on 03.02.2014 accepted for publication on 04.12.2015.

${ }^{2}$ Universidade Federal do Paraná, Laboratório de Operações Florestais, Curitiba, PR - Brasil. E-mail: <ricardomalinovski@ufpr.br>.

${ }^{3}$ Universidade Federal do Paraná, Laboratório Tecnologia da Madeira, Jardim Botânico, Curitiba, PR - Brasil. E-mail: $<$ leif.nutto@gmail.com>.

${ }^{4}$ Universidade Federal do Paraná, Laboratório de Operações Florestais, Curitiba, PR - Brasil. E-mail: <willianswiese@gmail.com>. ${ }^{5}$ Graduado em Engenharia Florestal, Albert-Ludwigs-Universität Freiburg, Freiburg, Alemanha. E-mail: $<$ martin.brunsmeier@fobawi.unifreiburg.de>.

${ }^{*}$ Corresponding author.
}

\begin{abstract}
The productivity of Eucalyptus at plantations is increasing and has undergone a variety of research studies. Most research is dealing with simple dendrometric variables like the DBH (diameter at breast height) and tree height, or more complex variables including crown parameters or variables concerning photosynthesis. The root systems, however, have not been well analyzed yet. The objective of the study was to analyze the root system with a non-destructive method and to evaluate possible correlations with dendrometric variables of the tree (DBH, height, crown expansion). A small experimental plantation with 39 even-aged, 6-yearold trees of Eucalyptus grandis $\mathrm{x}$ urophylla has been investigated within this study. The results of the study show the highest correlation of the root areas with the crown expansion. In general, the root area shows a significantly bigger expansion in the eucalypt plantation than the tree crown, with a more homogeneous development.
\end{abstract}

Keywords: Arboradix; Root expansion; Crown area.

\section{ANALISE NÃO DESTRUTIVA DO SISTEMA RADICULAR E PARÂMETROS DE CRESCIMENTO ARBÓREO}

\begin{abstract}
RESUMO - A produtividade de plantios de Eucalyptus está crescendo e tem sido tópico de muitas pesquisas. A grande maioria dos estudos trata das variáveis aéreas como DAP, área de copa ou número de galhos e seus diâmetros. As raizes, entretanto, ainda não foram propriamente estudadas. O presente trabalho apresenta resultados de um método não destrutivo com equipamento técnico que foi utilizado para determinar variáveis de uma árvore (DAP, altura, área de copa) que possivelmente se correlacionam com área radicular. Um pequeno plantio equiâneo com 39 individuos de Eucalyptus grandis $x$ urophylla aos seis anos de idade foi estudado no trabalho. Os resultados demonstraram que área radicular tem a correlação mais alta com área de copa. No geral, a expansão radicular é muito superior à área de copa para os indivíduos desse povoamento. Além disso, a expansão radicular demonstrou-se muito mais homogênea do que a área de copa.
\end{abstract}

Palavras-chave: Arboradix; Expansão radicular; Área de copa, 


\section{INTRODUCTION}

According to the Association of the Brazilian Producers of Planted Forests (ABRAF, 2011), Brazil has an area of planted forests of 6.5 million ha, being about 4.75 million ha covered by trees of the genus Eucalyptus. Since the 1960 s, the productivity raised from $10-15 \mathrm{~m}^{3} / \mathrm{ha} / \mathrm{yr}$ to $36-60 \mathrm{~m}^{3} / \mathrm{ha} / \mathrm{yr}$ (NEVES, 2008). This significant increase in wood increment was mainly reached by genetic improvement and improvement of soil preparation and fertilization.

Most studies of growth parameters subject deal with aboveground variables measured at the standing or felled tree. The role of the roots in all the physiological processes is not yet well analyzed, since data collection of this tree compartment is difficult and time consuming. Apart from these facts, the roots play an important role in anchoring, nutrient uptake, and water supply of the tree (RAVEN et al., 2007). Studies about root physiology are of great benefit for silviculture and forest management. One example is the study of Malinovski (1977), which could show a significant relation between root-system development and growth of aboveground biomass of Araucaria angustifolia. Tree roots may extend to a much wider area than the crown. In many cases, the aboveground competition leads to asymmetric crown development, which does not correspond to belowground root expansion (KUTSCHERA; LICHTENEGGER, 2002). However, the role of the root system for quantifying tree growth is not yet well understood due to the difficulties of finding appropriate techniques for evaluating the roots (JANSSENS et al., 2002). The problem is mainly based on the fact that excavating the root system is extremely time consuming and therefore expensive, thus leading to a lack of information compared to studies focusing on aboveground tree parameters (MEDINA; NEVES, 1999). It is obvious that it would be of great benefit to have more information about the extension of the root system and aboveground variables of a tree.

The lack of information about the root system is limiting the comprehension of the complex interaction in the forest ecosystem (VOGT et al., 1997). The bestknown methodology is the excavation of roots by applying the hydraulic method, the monolithic method, or rhizotron (BÖHM, 1979). All of these methods lead to damage or at least disturbances in the development of the root system, being destructive or semi-destructive methods.
Equipment for analyzing root systems of city trees was developed by the company Rinntech $\AA$. The ARBORADIX ${ }^{\circledR}$ is a kind of tomograph that allows measuring the extension of the root system in a nondestructive way by emitting impact signals that are conducted by the roots to a sensor at the tree. The ARBORADIX is a complementary sensor to the ARBOTOM $®$-system, which analyses the internal wood quality in standing trees by evaluating the speed of sound transmission caused by an impact between different sensors placed at the surface of the tree. The method may be classified as nondestructive but having the disadvantage of a relatively high price and the need of highly trained people for operating the system. The development of new methods for tree growth analysis including the root system would be highly useful for more comprehensive and effective silvicultural management systems (CONSTATINO, 2009). The objectives of the study therefore were:

- To evaluate the non-destructive measurement of the expansion of root system with the help of the ARBORADIX®.

To analyze the correlation between crown projection area, tree height, and diameter at breast height and the superficial root system expansion in a small plantation of a hybrid of Eucalyptus grandis $\mathrm{x}$ urophylla.

\section{MATERIALAND METHODS}

\subsection{Materials}

In total, 39 trees of a small experimental plantation were included in the study. The trees were from an even-aged, 6-year-old Eucalyptus grandis x urophylla stand at the geographical co-ordinates $26^{\circ} 26^{\prime} 50^{\prime \prime}$ South and $49^{\circ} 14^{\prime} 8.3^{\prime \prime}$ 'West, at an altitude of $920 \mathrm{~m}$ above sea level.

According to IBGE (2008) the climate of the study region is of type $\mathrm{Cfb}$ after the classification of Köppen. This climate is characterized as temperate with mild summers and well-distributed precipitation throughout the year and frost occurrence in winter.

At the study area, 50 trees were planted at $3 \mathrm{~m}$ $\mathrm{x} 2 \mathrm{~m}$ spacing. The natural mortality until age 6 was $22 \%$, reducing the stand to 39 trees. 


\subsection{Methods}

For the measurement of the root system, an ARBOTOM $®$ together with an ARBORADIX $\AA$ extension was used. The ARBOTOM $\AA$ equipment was developed by the German company RINNTECH. The system is based on the measurement of the velocity of an impulse induced by a hammer between two or more sensors connected by a firewire cable. The ARBORADIX ${ }^{\circledR}-$ extension allow fixing of an additional sensor iron bar and to measure the transmission of a signal via a root to the buttress of the subject tree. One sensor is connected at the tree feet, generally where the insertion of a root is visible; the other sensor fixed at the iron bar is taken in a prolongation and systematically hammered at given distances of $1 \mathrm{~m}$ in the soil. If the bar is getting close to a root, the signal is transmitted to the sensor at the tree. After each signal received by the tree sensor, the iron bar is taken another meter away from the tree and the procedure is repeated until no signal is received anymore. The direction of the iron bar is taken by a compass and inserted in the software ARBORADIX 2.0. The distances are also inserted and a two-dimensional graph can be generated by the software (see FIGURE 1).

The speed of the transmission is of no relevance in this case, only if the signal could be transferred or

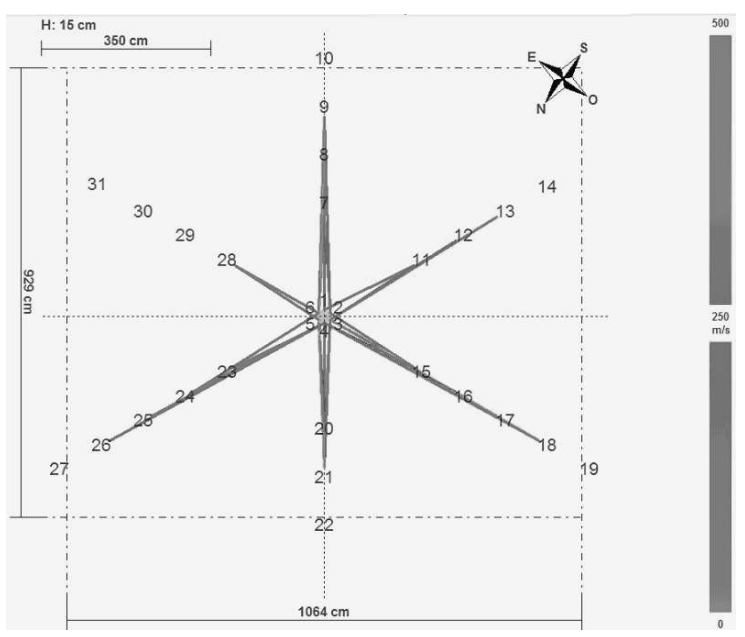

Figure 1 - Two-dimensional graph generated by the software ARBOTOM v2.0, showing distance and direction of the measurement points.

Figura 1-Gráfico bidimensional gerado pelo software ARBOTOM v2.0, mostrando a distância e direção dos pontos de medição. not between the two sensors. The points of root extensions are defined by direction (deviation from North = á) and distance (polar co-ordinates). The polar co-ordinates were transformed to Cartesian co-ordinates, where:

$$
\begin{aligned}
& \mathrm{X}=\sin \alpha * \text { distance } \\
& \mathrm{Y}=\cos \alpha * \text { distance }
\end{aligned}
$$

These co-ordinates are used for generating the root expansion area by linking the ends with a line, resulting in a polygon whose area can be calculated by using the equation:

$$
\begin{aligned}
& 2 * A=\left(X_{1}+X_{2}\right) *\left(Y_{2}-Y_{1}\right)+\left(X_{2}+X_{3}\right) *\left(Y_{3}-Y_{2}\right) \\
& +\ldots \ldots+\left(X_{n}+X_{1}\right) *\left(Y_{1}-Y_{n}\right)
\end{aligned}
$$

where: $\mathrm{A}=$ area of the polygon; $\mathrm{X}$ and $\mathrm{Y}$ are Cartesian co-ordinates; $\mathrm{N}=$ number of measurement points.

The variable crown base (cb) and tree height $(\mathrm{h})$ were measured with a Forestor Vertex IV®. Diameter at breast height (DBH) was measured with a diameter tape. Besides these variables, also the sociological class of each tree was evaluated by using the classification system of Kraft (1884). The system subdivides the trees into the following five classes:

- Class 1: pre-dominant trees;

Class 2: dominant trees;

Class 3: co-dominant trees;

- Class 4: dominated trees;

- Class 5: suppressed or already dead trees.

The evaluation of the sociological classes contains a set of subjective aspects that may lead to different evaluations in some cases.

Crown area was measured by marking the most representative points representing the real shape of the crown. Then the points were measured by taking the angle with a compass and distance with a measuring tape, with the subject tree being the center of the measurement. For calculating the crown area, the same procedure as for the root area was applied. In addition the position of all trees was determined in relation to a central tree, located more-or-less in the middle of the experimental plot. Having the position of each tree, plots of crown projection and root areas could be performed using a script for the software ArcView 3.2.

Revista Árvore, Viçosa-MG, v.40, n.2, p.289-295, 2016

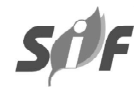




\section{RESULTS}

The trees of the experiment showed a mean height of $23.0 \mathrm{~m}$ with a standard deviation of $6.05 \mathrm{~m}$ ranging from a minimum of $10.1 \mathrm{~m}$ to a maximum of $37.3 \mathrm{~m}$.

The mean DBH was $24.3 \mathrm{~cm}$ with a standard deviation of $1.03 \mathrm{~cm}$ ranging from a minimum of 10.7 $\mathrm{cm}$ to a maximum of 34.1 .

Crown area had a mean value of $7.36 \mathrm{~m}^{2}$ and a standard deviation of $3.62 \mathrm{~m}^{2}$, and the observations ranged from $0.7 \mathrm{~m}^{2}$ to $15.8 \mathrm{~m}^{2}$.

The average root area was of $50.34 \mathrm{~m}^{2}$, but showed a variation between $11.7 \mathrm{~m}^{2}$ and $82.3 \mathrm{~m}^{2}$, and a standard deviation of $16.29 \mathrm{~m}^{2}$.

A correlation analysis of the growth and root variables showed a highly significant negative correlation between the social tree classes of Kraft and $\mathrm{DBH}$, tree height, crown area, and root area, with the coefficient of correlation with the root area being only -0.55 (TABLE 1 ). The coefficient of correlation of the root area was highest with crown area, reaching 0.59 . On the other hand, crown area was highly significant with the growth variables DBH and tree height, ranging between 0.87 and 0.82 respectively.

The study showed a strong correlation between crown area and $\mathrm{DBH}$, indicating that the larger the crown area the bigger the DBH (Figure 2). The linear model is:

Crown area $\left(\mathrm{m}^{2}\right)=0.5484 * \mathrm{DBH}(\mathrm{cm})-5.9848\left(\mathrm{R}^{2}\right.$ $=0.7603)$
As already shown, the correlation between root area and crown area is not as strong as between crown area and DBH (Figure 3). The coefficient of determination is 0.35 , indicating that $65 \%$ of the variability between both variables is not explained by the model:

Root area $\left(\mathrm{m}^{2}\right)=2.6736 *$ crown area $\left(\mathrm{m}^{2}\right)+30.665$ $\left(\mathrm{R}^{2}=0.35\right)$

\section{DISCUSSION}

The importance of research related to the root systems of forest trees for tree growth and stability is well known. Therefore the analysis of the root expansion is of essential importance for tree management in productive forests (HOFFMANN; USOLTSEV, 2001; SCHMID; KAZDA, 2001; KUIPER; COUTTS, 2001). One of the objectives of this study was to evaluate the possibility of non-destructive measurement of the root system with the equipment ARBORADIX. The results showed that it is possible to map root expansions of

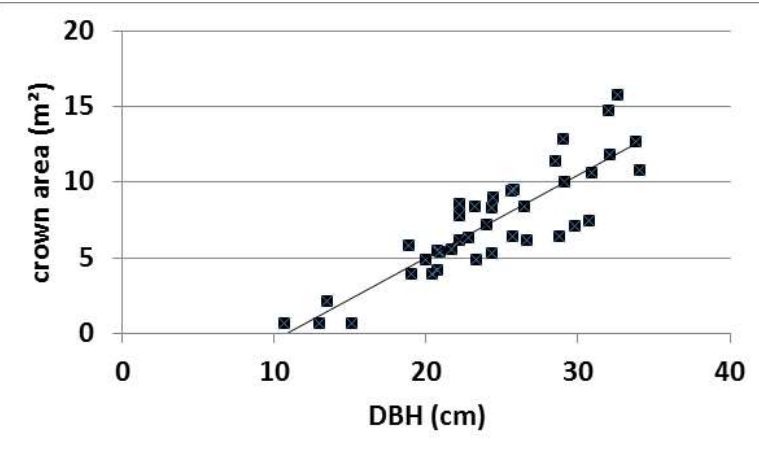

Figure 2 - Crown area $\left(\mathrm{m}^{2}\right)$ over DBH $(\mathrm{cm})$.

Figura 2 - Área de copa em $\mathrm{m}^{2}$ em função de DAP em $\mathrm{cm}$.

Table 1 - Pearson Correlation Coefficients, $\mathrm{N}=39$, Prob $>|\mathrm{r}|$ under H0: Rho $=0$.

Tabela 1 - Coeficientes de correlação de Pearson, $N=39$, Prob $>|r|$ sob H0: $R h o=0$.

\begin{tabular}{|c|c|c|c|c|c|}
\hline Variable & Kraft class & DBH & Height(m) & Crown area $\left(\mathrm{m}^{2}\right)$ & Root area $\left(\mathrm{m}^{2}\right)$ \\
\hline Kraft class & 1 & $\begin{array}{c}-0.85 \\
<.0001 \\
\end{array}$ & $\begin{array}{c}-0.82 \\
<.0001 \\
\end{array}$ & $\begin{array}{c}-0.75 \\
<.0001 \\
\end{array}$ & $\begin{array}{c}-0.55 \\
0.0003\end{array}$ \\
\hline DBH & $\begin{array}{c}-0.85 \\
<.0001\end{array}$ & 1 & $\begin{array}{c}0.75 \\
<.0001 \\
\end{array}$ & $\begin{array}{c}0.87 \\
<.0001 \\
\end{array}$ & $\begin{array}{c}0.55 \\
0.0003\end{array}$ \\
\hline Height & $\begin{array}{c}-0.82 \\
<.0001\end{array}$ & $\begin{array}{c}0.75 \\
<.0001\end{array}$ & 1 & $\begin{array}{c}0.82 \\
<.0001\end{array}$ & $\begin{array}{c}0.59 \\
<.0001\end{array}$ \\
\hline Crown area & $\begin{array}{c}-0.75 \\
<.0001\end{array}$ & $\begin{array}{c}0.87 \\
<.0001 \\
\end{array}$ & $\begin{array}{c}0.82 \\
<.0001 \\
\end{array}$ & 1 & $\begin{array}{c}0.59 \\
<.0001\end{array}$ \\
\hline Root area & $\begin{array}{c}-0.55 \\
0.0003\end{array}$ & $\begin{array}{c}0.55 \\
0.0003\end{array}$ & $\begin{array}{c}0.59 \\
<.0001\end{array}$ & $\begin{array}{c}0.59 \\
<.0001\end{array}$ & 1 \\
\hline
\end{tabular}

Revista Árvore, Viçosa-MG, v.40, n.2, p.289-295, 2016 


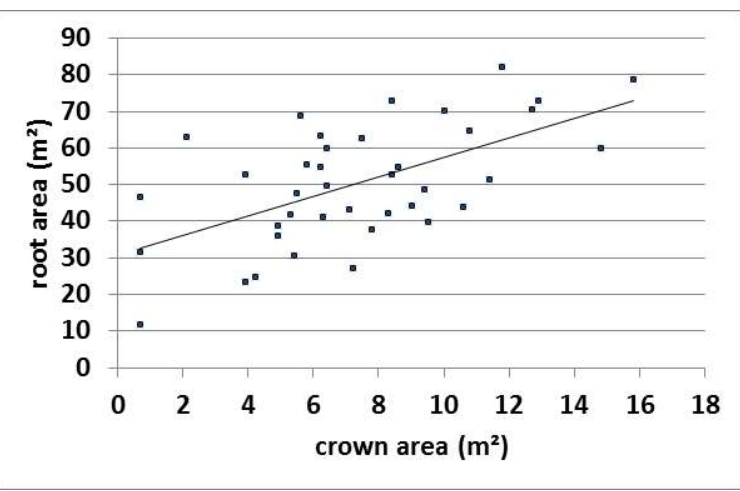

Figure 3 - Root area $\left(\mathrm{m}^{2}\right)$ over crown area $\left(\mathrm{m}^{2}\right)$.

Figura 3 - Área de raiz em $\mathrm{m}^{2}$ em função de área de copa $\mathrm{em} \mathrm{m}^{2}$.

the eucalypts using the ARBORADIX; however, up to now there are no experiences made with the precision of the system. Already Braun (1982) described the common fact of interlaced roots in forest trees of several species. Florence (1996) stated strong evidence of root interlacing in eucalypt forests. Since the measurement principle of the ARBORADIX is based on the signal transmission after an impact from the root to the tree, it cannot be excluded that a transfer of the signal is occurring from the root system of another tree to the subject tree, indicating a larger root expansion than exists in reality. The results might overestimate the real root expansion. Beside this, the limited length of the sensor bar (in this study 80 $\mathrm{cm}$ ) may not reach roots that have greater expansion but run in deeper layers.

Validating the measurements made with the help of ARBORADIX using a destructive method like excavating the roots or applying more sophisticated technologies like Geophysical Imaging Techniques (HAGREY, 2012), Multi-electrode Resistivity Imaging (AMATO et al., 2012) or Ground-Penetrating Radar (BUTNOR et al., 2012) would be recommended. In nondestructive methods, factors like soil texture or soil moisture content may have influence on the performed measurements, indicating that further research on the impact of these variables are necessary for making a final evaluation of the ARBORADIX. The presented results should be evaluated critically in regard to these aspects.

The results of this study match with the findings of Laclau et al. (2001) who found a high heterogeneity of the root systems in stands of Eucalyptus. If grouped in classes of root area, the graph shows that the distribution of the data is close to Gaussian distribution. It means that the root areas in this population have a symmetric distribution with respect to the mean and, therefore, approximately $50 \%$ of the area under the curve lies to the left of the mean value and $50 \%$ to the right of the mean value.

According to Köstler et al (1968), the expansion of the root system is closely related to the aboveground crown size. The plot of crown and root area show a more homogeneous development of the root area, while the crowns develop towards an open area as can be shown with the border trees (Figure 4). Asymmetric crown development is very common if competition is coming from only one side. The root area may also be much bigger than the crowns, indicating overlapping of roots between the different individuals. In the present study, expansion of the root system is bigger than the area covered by the crown. According to Kutschera and Lichtenegger (2002), tree roots may extend to a much wider area than the crown. In many cases, the aboveground competition leads to asymmetric crown development, which does not correspond to belowground root expansion. This might also be the case in the small eucalyptus plantation used in this study.

The relationship between crown size and root biomass is well known from the literature. On the other hand, the strong relationship between crown size and tree diameter has been shown for many eucalypts and other tree species (NUTTO et al., 2003; BIECHELE et al., 2009). Several authors could show correlations between root size and aboveground growth parameters. Drexhage and Colin (2001) estimated root system biomass from the diameter at breast height, while Schmid and Kazda (2001) also found a correlation between vertical distribution of roots and tree growth. The relationship between crown size and root expansion in this study is not as strong, but indicates that there is a relationship between both variables. The results might be, as already indicated, influenced by the methodology applied and the lack of validation of the equipment for such research. Even so, the first results are promising but further research is needed to get more reliable results.

\section{CONCLUSIONS}

A non-destructive method to measure the expansion of the root system and possible correlation between the DBH and the crown expansion was used. There

Revista Árvore, Viçosa-MG, v.40, n.2, p.289-295, 2016

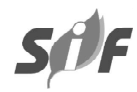




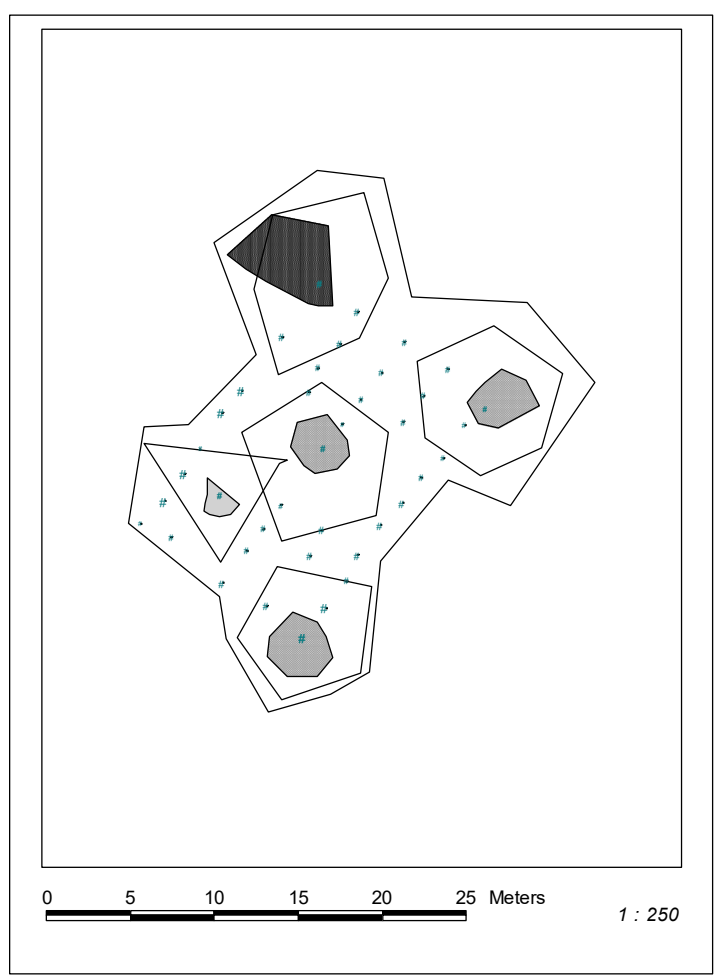

Figure 4- Plot of crown and root projection area of five selected trees. The darker areas represent the crown areas, while the lighter polygons show the root area of the respective trees. A plot of all data would result in confusion because of overlapping.

Figura 4 - Plotagem de áreas de coroa e raiz de 5 árvores selecionadas. A área em tom mais escuro representa a área de copa, enquanto os polígonos em tons mais claros representam a área de raiz da respectiva árvore. Uma plotagem de todos os dados dificultaria a visualização devido à sobreposição.

is a need for professional skills in order to use the technical equipment, but the tools once installed reveal the stem quality and the root system, and help to understand the highly complex ecological matter of roots and their growth and their expansion.

The highest correlation with the root development can be found with the crown expansion. The results also show that the root area develops much bigger than the crowns and develops more homogeneously.

There is a high heterogeneity of the root systems in stands of Eucalyptus, but if grouped in root area classes, the graph shows a normal curve of distribution.
The used equipment needs further validation for being used in the non-destructive evaluation of root systems of forest trees.

There might be other external influences that have to be investigated and measured. Even destructive methods could be used to verify the findings and results of this study.

\section{REFERENCES}

ABRAF. Anuário estatístico da ABRAF 2011 ano base 2010 /ABRAF. Brasília: 2011.

AMATO, M.; LAPENNA, V.; ROSSI, R., BITELLA, G. Multi-electrode Resistivity Imaging. In: MANCUSO, S. Measuring roots. New York: Springer, 2012. p.189-213.

BIECHELE, T.; NUTTO, L.; BECKER, G. Growth strain in Eucalyptus nitens at different stages of development. Silva Fennica, v.43, n.4, p.669$679,2009$.

BÖHM, W. Methods of studying root systems. Berlin: Springer Verlag, 1979.

BRAUN, H. Lehrbuch der Forstbotanik. New York: Fischer Verlag, 1982.

BUTNOR, J.R.; BARTON, C.; DAY, F.P.; JOHNSEN, K.H.; MUCCIARDI, A.N.; SCHROEDER, R.; STOVER, D.B. Using ground penetrating radar to detect tree roots and estimate biomass. In: MANCUSO, S.

Measuring roots. New York: Springer, 2012. p.213-231.

CONSTATINO, V. Efeitos de métodos de produção de mudas e equipes d e plantadores na arquitetura do sistema radicular e n o crescimento de Pinus taeda Linnaeus. 2009. 146f. Dissertação de (Mestrado em Engenharia Florestal) Universidade Federal do Paraná, Curitiba, 2009.

DREXHAGE, M.; COLIN, F. Estimation root system biomass from breast-height diameters. Forestry, v.74, p.491-497, 2001.

FLORENCE, R.G. Ecology and Silviculture of Eucalypt Forests. Collingwood: CSIRO Publishing, 1996. 
HAGREY, S.A. Geophysical Imaging Techniques. In: MANCUSO, S. Measuring roots. Dordrecht: Springer, 2012. p.151-188.

HOFFMANN, C.W.; USOLTSEV, V.A. Modelling root biomass distribution in Pinus sylvestris forests of the Turgai Depression of Kazakhstan. Forest Ecology and Management, v.149, p.103-114, 2001.

\section{INSTITUTO BRASILEIRO DE GEOGRAFIA E} ESTATÍSTICA - IBGE. Mapeamento Geográfico (on-line). 2008.Disponível em http:// www.ibge.gov.br/mapas. [Acessado em junho de 2013].

JANSSENS, I.A.; SAMPSON, D.A.; CURIELYUSTE, J.; CARRARA, A.; CEULEMANS, R. The carbon cost of root turnover in a Scots pine forest. Forest Ecology and

Management, v.168, p.231-240, 2002.

KÖSTLER, N.; BRÜCKNER, E.; BIEBELRIETHER, H. Die Wurzeln der Waldbäume. The roots of forest trees. Paul Parey: Verlag, 1968.

KRAFT, G. Beiträge zur Lehre von den Durchforstungen, Schlagstellungen und Lichtungshieben [Contributions to the Science of Thinnings, Coupe Designs and Interventions for Light Management]. Hannover: 1884.

KUIPER, L.C.; COUTTS, M.P. Spatial disposition and extension of the structural root system of Douglas-fir. Forest Ecology and

Management, v.47, p.111-125, 2001.

KUTSCHERA, L.; LICHTENEGGER, E. Wurzelatlas mitteleuropäischer Waldbäume und Sträucher. Root atlas of forest in Middle Europe Graz: Leopold Stocker Verlag, 2002.

LACLAU, J.P.; ARNAUD, M.; BOUILLET, J.P.; RANGER, J. Spatial distribution of Eucalyptus roots in a deep sandy soil in the Congo: relationships with the ability of the stand to take up water and nutrients. Tree Physiology, v.21, n.1, p.129-136, 2001

MALINOVSKI, J.R. Métodos de poda radicular em Araucaria angustifolia Kuntze e seus efeitos sobre a qualidade de mudas em raiz nua. Curitiba: UFPR, 1977.

MEDINA, C.C.; NEVES, C.S.V.J. Método da trincheira com contagem manual das raízes. In: WORKSHOP SOBRE SISTEMA RADICULAR metodologias e estudo de casos. Anais... Aracaju: Embrapa Tabuleiros Costeiros, 1999. p.275-282.

NEVES, J.C.L. Monitoramento nutricional e recomendação de adubação. Apresentação no Encontro Nacional de Silvicultura. Curitiba: 2008.

NUTTO, L.; SPATHELF, P.; ROGERS, R.. Managing diameter growth and self-pruning of Parana pine, Araucaria angustifolia (Bert.) $\mathrm{O}$ Ktze., to produce high value timber. Annals of Forest Science, v.62, p.163-173, 2003.

RAVEN P.H.; EVERT, R.F.; EICHHORN, S.E. Biologia vegetal. 7.ed. Rio de Janeiro: Guanabara Koogan, 2007.

SCHMID, I.; KAZDA, M. Vertical distribution and radial growth of coarse roots in pure and mixed stands of Fagus sylvatica and Picea abies.

Canadian Journal of Forestry, v. 31, p.539-548, 2001.

VOGT, K.; ASBJORNSEN, H.; ERCELAWN, A.; MONTAGNINI, F.; VALDÉS, M. Roots and mycorrhyzas in plantation ecosystems. In: NAMBIAR, E.K.S.; BROWN, A.G. (Ed). Management of soil, nutrients and water in tropical plantation forests. Canberra: ACIAR, 1997. p.247-296. 